Geosistemy perehodnykh zon = Geosystems of Transition Zones / Геосистемы переходных зон

Content is available under the Creative Commons Attribution 4.0 International License (CC BY 4.0)

2020, vol. 4, No. 4, pp. 384-392

URL: http://journal.imgg.ru/archive.htm ; https://elibrary.ru/title about.asp?id=64191

https://doi.org/10.30730/gtrz.2020.4.4.384-392

\title{
Application of high resolution seismic to search for local gas anomalies in the South Kirinskoye oil and gas condensate field
}

\author{
Vasilii K. Leksin \\ «RN-SakhalinNIPImorneft» Limited Liability Company, Yuzhno-Sakhalinsk, Russia \\ E-mail: lex-vasya@mail.ru
}

\section{Abstract PDF ENG Резюме PDF RUS $\quad$ Full text $\underline{\text { PDF RUS }}$}

Abstract. Searches for local gas anomalies in water areas are necessary to improve the safety of the construction of offshore oil and gas production facilities. The article presents the results of studies of geological hazards at the South Kirinskoye oil and gas condensate field using high resolution seismic from 2010 to 2017. New high-quality seismic sections, reduced to a single type and level, were built, which to make a correlation of reflecting horizons and map geological hazards at intersecting research sites of different years. Based on the results of the interpretation of seismic sections, local anomalies were found in the upper part of the section, indicating the presence of gas. By the structural features of the bedding in the channel on seismic sections, a turbidite flow was detected at a depth of $900 \mathrm{~m}$ from the seabed with a width of $1000 \mathrm{~m}$ and a length of more than two and a half kilometers. Correlations between the amplitude on the seismic section and the value of methane content (C1) in the drilling fluid on the log were revealed. The result of the work is the first compiled consolidated map of all geological hazards within the South Kirinskoye oil and gas condensate field, discovered as a result of the interpretation of seismic sections.

\section{Keywords:}

\section{geological hazards, high resolution seismic, seismic section, gas anomalies}

For citation: Leksin V.K. Application of high resolution seismic to search for local gas anomalies in the South Kirinskoye oil and gas condensate field. Geosistemy perehodnykh zon = Geosystems of Transition Zones, 2020, vol. 4, no. 4, pp. 384-392. (In Russ., abstr. in Engl.). https://doi.org/10.30730/gtrz.2020.4.4.384-392

Для цитирования: Лексин В.К. Применение сейсморазведки высокого разрешения для поисков локальных газовых аномалий на Южно-Киринском нефтегазоконденсатном месторождении. Геосистемы переходных зон, 2020, т. 4, № 4, c. 384-392. https://doi.org/10.30730/gtrz.2020.4.4.384-392

\section{References}

1. Akulichev V.A., Obzhirov A.I., Shakirov R.B., Maltseva E.V., Gresov A.I., Telegin Yu.A. 2014. Conditions of gas hydrate formation in the Sea of Okhotsk. Doklady Earth Sciences, 454(1): 94-96. https://doi.org/10.1134/s1028334x14010164

2. Baranov B.V., Dozorova K.A., Rukavishnikova D.D. 2015. Hazardous geological processes on the eastern slope of Sakhalin. Oceanology, 55(6): 906-909. http://doi.org/10.7868/S0030157415060027

3. Bogoyavlensky V.I., Kerimov V.Yu., Olkhovskaya O.O., Mustaev R.N. 2016. Improving the efficiency and safety prospecting, exploration and development of oil and gas in the Sea of Okhotsk. Territoriya Neftegaz [Oil and gas territory], 10: 24-32. (In Russ.).

4. Veselov O.V., Gordienko V.V., Kudelkin V.V. 2006. [Thermobaric conditions for the formation of gas hydrates in the Sea of Okhotsk]. Geology and Mineral Resources of World Ocean, 4: 42-65. (In Russ.).

5. Gavrilov A.A. 2009. The role of faults in the formation of the coastlines of the Okhotsk Sea and Sea of Japan (paper 1. Regional aspect of studies). Geomorfologiya, 3: 38-49. (In Russ.).

6. Gaynanov V.G. 2008. [On the use of dynamic recording parameters in seismoacoustic profiling]. Vestnik Moskovskogo universiteta, Seriia 4, Geologiia = Moscow University Geology Bull., 5: 33-39. (In Russ.).

7. Golubin S.I., Saveliev K.N., Novikov A.N. 2019. Estimation of geological hazards in the operational monitoring of offshore fields of Sakhalin Island. Gazovaya promyshlennost' = Gas Industry Magazine, S1 (782): 30-35. (In Russ.).

8. Dzyublo A.D., Voronova V.V., Perekrestov V.E. 2019. Research shallow gas of Sakhalin shelf and minimize risks during offshore wells construction. Vestnik Assotsiatsii burovykh podryadchikov = Bull. of the Association of Drilling Contractors, 3: $20-25$. (In Russ.).

9. Ivanov G.I., Kazanin A.G., Sarkisyan M.V., Lantsev V.V., Nekrylov N.T., Ionov V.Yu., Pavlov S.P., Makarov E.S. 2016. [Highresolution seismics - a new step forward in the study of geological hazards]. Neft. Gaz. Novatsii. [Oil. Gas. Innovations], 1: 6568. (In Russ.).

10. Kerimov V.Y., Sizikov E.A., Sinyavskaya O.S., Makarova A.Y. 2015. The conditions of the formation and the searching of hydrocarbon deposits in the turbidite reservoirs on the Okhotsk offshore. Neft', gaz i biznes [Oil, Gas and Business], 2: 32-37. (In Russ.).

11. Lalomov D.A., Korshunov D.A., Musin M.V., Razmatova A.V. 2019. Regionalization of shallow gas distribution sites in the gulf of Ob based on statistical analysis of seismoacoustic data. Inzhenernye izyskaniya = Engineering Survey, 13(3): 50-59. (In Russ.). 
12. Leksin V.K., Samarin V.I., Liskovyi P.N. 2018. Results of interpretation of seismic during engineering surveys within of the South-Kirinskoye oil and gas condensate field (shelf of Sakhalin Island). Inzhenernye izyskaniya= Engineering Survey, 12(9-10): 64-73. (In Russ.).

13. Mironyuk S.G., Roslyakov A.G., Semenova A.A., Sharipov M.S. 2017. Using high-resolution seismics for identification of geological hazards in various geomorphological zones of the Black sea. Inzhenernye izyskaniya = Engineering Survey, 1: 54-60. (In Russ.).

13. Novikov A.A. 2018. Specifics of the integrated offshore geotechnical investigations and estimation of geological hazards for objects of the subsea production system of the offshore fields of Kirinsky block of Sakhalin Island. Gazovaya promyshlennost' = Gas Industry Magazine, 9: 42-48. (In Russ.).

15. Petrenko V.E., Oganov G.S., Sviridova T.A. 2017. Shallow gas: risks and variants of technical-technological solutions when projecting construction of offshore wells. Oborudovanie $i$ tekhnologii dlya neftegazovogo kompleksa = Equipment and technologies for oil and gas complex, 2: 21-27. (In Russ.).

16. Rybalchenko V.V., Gogonenkov G.N., Slepchenko V.A. 2017. Vertical gas migration and gas hydrates in the northeast shelf of Sakhalin. Oil and Gas Geology, 2: 38-51. (In Russ.).

17.Telegin A.N. 2004. [Marine seismic exploration]. Moscow: Geoinformmark, 237 p. (In Russ.).

18. Hilterman F.J. 2010. Interpretation of amplitudes in seismic exploration. Tver: Publ. House of the GERS, 256 p. (In Russ.). (Translation from: Hilterman F.J. 2001. Seismic amplitude interpretation. Society of Exploration Geophysicists, 236 p.).

19. Sheriff R.E., Geldart L.P. 1983. Exploration Seismology. 2: Data - processing and interpretation. London: Cambridge University Press, $231 \mathrm{p}$.

20. Yilmaz Öz. 2001. Seismic data analysis - processing, inversion, and interpretation of seismic data. Tulsa: SEG, 2025 p. https://doi.org/10.1190/1.9781560801580 